\title{
Qualitative Analysis of Hydroxyurea
}

\author{
Stéfanno Souza Santos ${ }^{* a}$, Isis Gomes dos Santos ${ }^{\mathrm{a}, \mathrm{b}}$, Cinara Vasconcelos da Silva ${ }^{\mathrm{a}}$, Edith Cristina Laignier Cazedey ${ }^{\mathrm{a}, \mathrm{b}}$
}

${ }^{a}$ Núcleo de Pesquisa e Análise de Medicamentos (NuPAM), Departamento do Medicamento, ${ }^{b}$ Programa de Pós-Graduação em Farmácia (PPGFAR), Faculdade de Farmácia, Universidade Federal da Bahia, Rua Barão de Jeremoabo, s/n, 40170-290, Salvador, Bahia, Brazil

\section{*Corresponding author: stefannodm@gmail.com}

Hydroxyurea (HU) is a cytostatic agent with antineoplastic activity and presents great clinical efficacy in the treatment of sickle cell disease. The drug is part of Brazilian National List of Essential Medicines and despite its clinical importance, HU does not present monography in Brazilian Pharmacopoeia. This study aimed to develop qualitative methods for HU identification and purity verification. In addition to organoleptic tests, it was used IR and UV spectroscopy, as well as TLC. The IR and UV spectra showed compatibility and the maximum absorption at $213 \mathrm{~nm}$. For TLC, various pure or polarity gradient solvents were tested with results satisfactory for a mobile phase containing acetone and ethyl acetate $(99: 1, \mathrm{v} / \mathrm{v})$. In this last case, the replacement of the mobile phase from those described on pharmacopeias generated less chemical waste, while minimizing the risks to operator's health, in accordance with the main concept of green analytical chemistry. Therefore, in this work was presented three excellent qualitative green methods for identifying quick and easily hydroxyurea.

Keywords: hydroxyurea; hydroxycarbamide; qualitative analyses; quality control; green analytical chemistry. DOI: https://doi.org/10.22456/2527-2616.100682

\section{Introduction}

Hydroxyurea (HU) (Figure 1), also known as hydroxycarbamide, CAS 127-07-1, is a white or almost white, crystalline and hygroscopic powder. $\mathrm{HU}$ is easily soluble in water and practically insoluble in ethanol [1-4]. This drug presents molecular formula $\mathrm{CH}_{4} \mathrm{~N}_{2} \mathrm{O}_{2}$, molecular weight $76,055 \mathrm{~g} \mathrm{~mol}^{-1}$, melting point $142-146{ }^{\circ} \mathrm{C}$, pKa 10.14 (strongly acidic) and $\log \mathrm{P}-1.8$ [5].<smiles>NC(=O)NO</smiles>

Figure 1. Chemical structure of hydroxyurea

HU was originally synthesized in 1869 , however its potential biological importance was recognized only in 1928 [6]. Despite being widely used in treatment of neoplastic diseases, myeloid leukemia, psoriasis, and polycythemia vera, HU mechanism of action has not been completely elucidated [7,8]. As far as is known, HU belongs to the class of antimetabolites and acts by inhibiting the enzyme ribonucleotide reductase, present in DNA biosynthesis, keeping it in the $\mathrm{S}$ phase of the cell cycle $[9,10]$.

According to its mechanism of action, literature indicates the use of HU also to the treatment of sickle cell diseases (SCD) pathophysiology, as it performs by promoting the synthesis of fetal hemoglobin (FHb). Thus, HU contributes to the reduction of vessel-occlusive and inflammatory events in patients with SCD, being the first drug that reduces clinical complications and improves patients' quality of life [11].

Further, HU is part of the Brazilian National List of Essential Medicines (RENAME) [12] corroborating its importance. However, despite its clinical relevance and wide usage, this drug is not included in the Brazilian Pharmacopoeia (FB). FB is a crucial pharmaceutical compendium that establishes, through methods and monographs, the minimum quality, authenticity and purity requirements of pharmaceutical ingredients and medicines, and institutes the products acceptability parameters available to the Brazilian population [13]. Therefore, to guarantee methods and specifications for medicines, in absence of monographs in FB, the National Health Surveillance Agency (ANVISA) allows the use of some official compendia including for $\mathrm{HU}$, the European, American, Portuguese and British Pharmacopoeias [1-4]. Anyhow, these monographs do not always present concordant aspects such as the instrumentation available or commonly used in Brazil or the strong trend in green analytical chemistry [14-15].

From this perspective, it is necessary to develop qualitative methods capable of admit drug authenticity and ensure its identification and purity. Given the above, the present work aimed to develop qualitative analytical methods for $\mathrm{HU}$ quality control active pharmaceutical ingredient (API) and finished product - capsules, related to organoleptic characteristics, infrared (IR) spectrometry, ultraviolet (UV) spectrophotometry and thin layer chromatography (TLC).

\section{Experimental}

\section{Chemicals and reagents}

HU standard reference (SR) was obtained from European Pharmacopeia with a declared content of $99.9 \%$, lot Y000019. HU API was purchased from Sigma Aldrich ${ }^{\circledR}$, declared content of $101.0 \%$, lot MKBX3764V. HU samples were capsules, containing $500 \mathrm{mg}$, named Hydrea ${ }^{\circledR}$, reference mark (Bristol-Myers Squibb ${ }^{\circledR}$ LTDA). All chemicals and reagents used were of analytical grade: acetone (Alphatec ${ }^{\circledR}$, Brazil), ethyl acetate (Alphatec ${ }^{\circledR}$, Brazil), chloroform (Vetec ${ }^{\circledR}$, Brazil), 4-dimethylaminobenzaldeyde $\left(\right.$ Merck $^{\circledR}$, Germany), dichloromethane (Exxodo ${ }^{\circledR}$, Brazil); hexane (Merck ${ }^{\circledR}$, Germany), methanol (Alphatec ${ }^{\circledR}$, Brazil), pyridine $\left(\right.$ Merck $^{\circledR}$, Germany), urea (Alphatec ${ }^{\circledR}$, Brazil). Ultrapurified water was obtained by Milli-Q system, Millipore ${ }^{\circledR}$. 


\section{Instrumentation}

HU SR, API and samples were analyzed by Attenuated Total Reflection Fourier Transform Infrared (ATR-FTIR) spectroscopy at 70 scans with $4 \mathrm{~cm}^{-1}$ resolution, between 4000 and $400 \mathrm{~cm}^{-1}$ using a Golden Gate Single Reflection Diamond ATR accessory (Vertex 70v, Bruker ${ }^{\circledR}$ ). It was also employed an UV spectrophotometer, UV-1800 (Shimadzu ${ }^{\circledR}$ ) in the wavelength range from 200 to $400 \mathrm{~nm}$ using $10 \mathrm{~mm}$ quartz cell. To TLC analysis were used aluminum plate, silica gel 60 coated with fluorescent indicator F254, with a thickness of $0.20 \mathrm{~mm}$ (Alugram ${ }^{\circledR}$, Germany), activated in an oven at $105{ }^{\circ} \mathrm{C}$ for 1 hour.

\section{Preparation of standards and samples solutions}

Stock solutions of $1000 \mu \mathrm{g} / \mathrm{mL}$ of HU SR, API and capsules were prepared using water as solvent. The work solutions were prepared by dilution of the stock solutions with water in a final concentration of $100 \mu \mathrm{g} / \mathrm{mL}$. For thin layer chromatography, solutions of HU API and urea with a final concentration of $50 \mathrm{mg} \mathrm{mL}^{-1}$ and $10 \mathrm{mg} \mathrm{mL}^{-1}$ for dimethylaminobenzaldehyde revealing solution were used.

\section{Procedures}

Organoleptic characteristics of hydroxyurea - Organoleptic tests provide parameters for immediate detection of quality deviations of a sample through characteristics detectable by sense organs such as appearance, color, odor, taste and touch [16]. HU SR, API and intact capsules were observed for appearance, color and odor.

ATR-FTIR - HU SR and sample was put directly into the ATR probe.

UV spectrophotometry absorption - To identify the HU molecule by UV spectrophotometry it was necessary to select the appropriate solvent and the maximum wavelength. Samples containing HU were scanned in $0.1 M$ hydrochloric acid $(\mathrm{HCl}), 0.1 M$ sodium hydroxide $(\mathrm{NaOH})$, water, water and ethanol (70:30, v/v), water and methanol (95: 05, v/v) and acetonitrile and water (90:10, v/v).

$T L C$ - A small amount of HU API and urea solutions were spotted near the bottom of the TLC plate and it followed classic procedure. The solution components were visualized after the application of the revealing solution.

\section{Results and discussion}

\section{Hydroxyurea organoleptic characteristics}

The HU samples analyzed were compatible with organoleptic characteristics described in the official monographs [1-4], presenting as a white or almost white, odorless, crystalline and hygroscopic powder. Although the organoleptic tests are only indicative of identity - do not have decisive character in the analysis, mainly due to their subjectivity, it can help in detecting possible nonconformities, integrity or appearance of API and pharmaceuticals and thus assist in the initial assessment of drug stability [17].

\section{Identification of hydroxyurea by infrared spectrophotometry}

The absorption spectrum interpretation allows identification of pharmaceutical substances with great accuracy [18].

When analyzing the HU IR spectra, it should be considered that this drug is a small molecule that has few chemical bonds. Consequently, the HU has a reduced number of stretches (Table 1).

Table 1. FTIR data of hydroxyurea

\begin{tabular}{|c|c|}
\hline $\begin{array}{c}\text { Wavenumber } \\
\left(\mathbf{c m}^{-1}\right)\end{array}$ & Functional group/Assignment \\
\hline 3416 & Aliphatic primary amine, $\mathrm{NH}$ stretch \\
\hline 3310 & $\begin{array}{c}\text { Aliphatic secondary amine, NH stretch } \\
\text { O-H stretch (possible overlay) }\end{array}$ \\
\hline 2810 & C-H stretch of an aliphatic compound $*$ \\
\hline 1635 & $\begin{array}{c}\mathrm{C}=\mathrm{O} \text { stretching vibration of carbonyl group } \\
\text { and/or amide }\end{array}$ \\
\hline 1585 & Amide bonding \\
\hline
\end{tabular}

The spectrum region $<1500 \mathrm{~cm}^{-1}$ presents complex absorption and is difficult to point functional groups [18]. Hence, this region was not adopted for drug identification.

In addition, to identifying HU molecule by the stretch bands in IR spectrum, an overlay can also be done. In this case, the absorption spectrum of the sample should be similar to the spectrum of the HU SR (Figure 2).
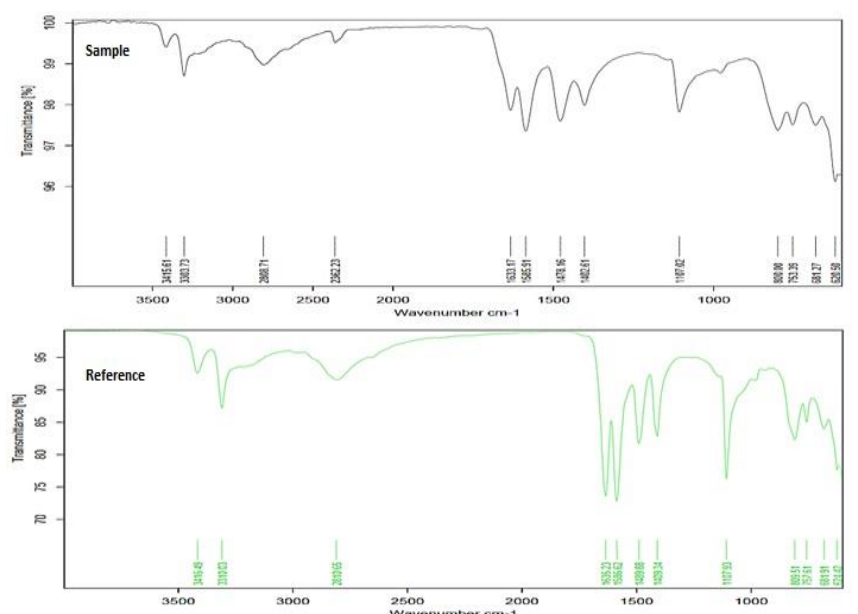

Figure 2. Hydroxyurea infrared spectrograms: A) HU API; B) HU SR

\section{Identification of hydroxyurea by ultraviolet spectrophotometry}

For identification using UV spectrophotometry technique, according to FB 6 (2019) [13], the drug should be dissolved in an appropriate solvent that does not absorb in the same spectral region where the molecule does. Experimentally, it was verified that $\mathrm{HU}$ presented similar absorption behavior in water, $0.1 \mathrm{M} \mathrm{HCl}$, acetonitrile and water (90:10, v/v), water and ethanol (70:30, v/v) and water and methanol (95:05 v/v), 
except in $0.1 M \mathrm{NaOH}$, which presented noise around 200 to $230 \mathrm{~nm}$ (Figure 3).

Thereby, given the possibility of using almost all tested solvents for HU analysis, water was chosen for identification tests, presenting maximum absorbance in $213 \mathrm{~nm}$. Water was considered due to its many advantages, such as acquisition cost and non-toxicity to the analyst and environment (renewable and safer solvent). Besides that, this solvent is a sustainable option, giving continuity to the scientific development supported by green analytical chemistry and minimizing the emission of contaminants, making laboratory practices more environmentally friendly [15].

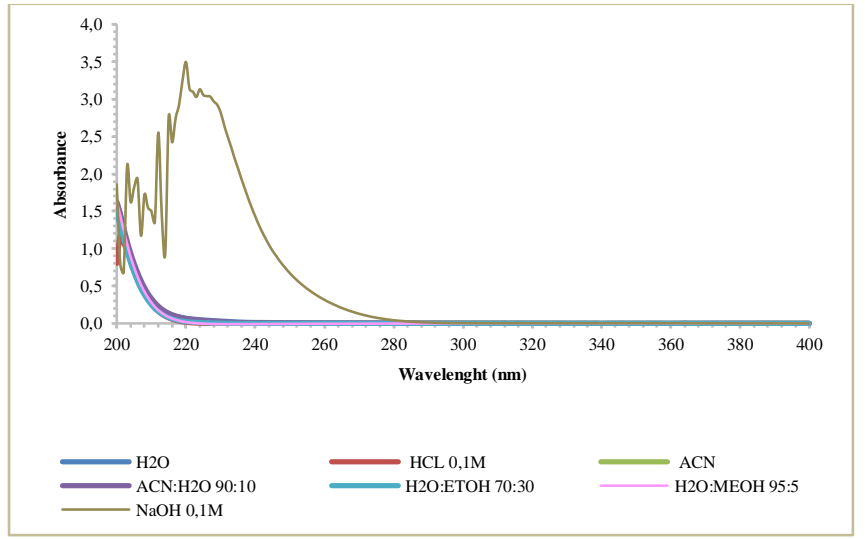

Figure 3. HU absorption profiles with different solvents.

\section{Identification of hydroxyurea by thin layer chromatography}

Another identification test was developed using TLC. This technique is a flexible approach that allows drugs and impurities (urea) to be determined, by molecules differential affinities towards the stationary and mobile phase resulting in the differential separation of the components.

According to Figure 4, the solvent systems with the best resolution for HU and urea analysis were systems 2, 3 and 4, which presented $\mathrm{Rfs}$ in the middle of the plate and close to that obtained in the pharmacopoeial methods (system 1). However, system 4 - composed by acetone and ethyl acetate (99:1, v/v) was selected once it exhibited, besides satisfactory $\mathrm{Rf}$, absence of tail and less toxic solvents to both environment and analyst, compared to the American Pharmacopoeial system. In addition, solvents selected for the proposed method are commonly used in the laboratory and therefore more affordable, reducing the costs of analysis. Given the above, the TLC method developed can be used in the routine of small laboratory and quality control of large industries.
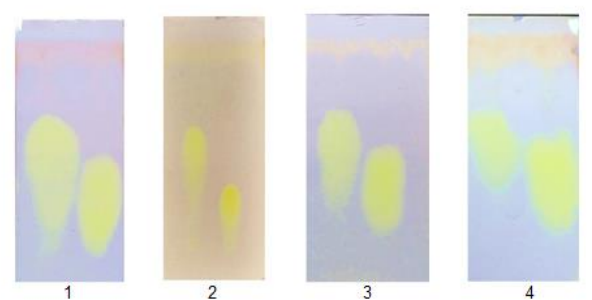

Figure 4. Comparative HU TLC profiles: 1) pyridine, water and acetate $(2: 2: 10, \mathrm{v} / \mathrm{v} / \mathrm{v}) ; 2)$ Acetone: chloroform $(9: 1, \mathrm{v} / \mathrm{v})$; Acetone: dichloromethane $(99: 1, \mathrm{v} / \mathrm{v})$; 4) Acetone: ethyl acetate $(99: 1, \mathrm{v} / \mathrm{v})$.

\section{Conclusions}

This work presents great relevance and application in the $\mathrm{HU}$ identification using IR spectroscopy, UV spectrophotometry and TLC. Moreover, the developed methods suggest the use of relative low-cost solvents, with low risk and hazard (toxicity) for analyst and environment, characterizing as sustainable options - greening laboratory practices and minimizing the emission of contaminants.

\section{Acknowledgments}

The authors acknowledge FAPESB under contract TO JCB 0013/2016 and PROPG/UFBA.

\section{References}

1. European Pharmacopoeia. 10th. ed. Strasbourg: Council of Europe, 2020.

2. United States Pharmacopeia. USP 43-NF 38. Rockville: The United States Pharmacopoeial Convention, 2020.

3. Farmacopeia Portuguesa, IX. Lisboa: Instituto Nacional da Farmácia e do Medicamento, 2008.

4. British Pharmacopoeia. London: Her Majesty's Stationery Office, 2016.

5. PUBCHEM. Hydroxyurea. Available from: https://pubchem.ncbi.nlm.nih.gov/compound/hydroxyure a. [Accessed 10 April 2020].

6. Brunton LL, Hilal-Dandan R. Manual de Farmacologia e Terapêtica de Goodman \& Gilman. Porto Alegre: AMGH, 2010.

7. Jiang J, Jordan SJ, Barr DP, Gunther MR, Maeda H, Mason RP. In vivo production of nitric oxide in rats after administration of hydroxyurea. Mol Pharmacol. 1997; 52(6): 1081-1086.

8. Seguin CSA. Influência da hidroxiureia nas propriedades adesivas de neutrófilos e plaquetas. [dissertation]. Campinas (SP): Universidade Estadual de Campinas, 2017.

9. Boyd AS, Neldner KH. Hydroxyurea therapy. J Am Acad Dermatol. 1991; 25(3): 518-524.

10. Kovacic P. Hydroxyurea (therapeutics and mechanism): metabolism, carbamoyl nitroso, nitroxyl, radicals, cell signaling and clinical applications. Med Hypotheses. 2011; 76(1): 24-31.

11. Cançado RD, Lobo C, Ângulo IL, Araújo PI, Jesus JA. Protocolo clínico e diretrizes terapêuticas para uso de hidroxiureia na doença falciforme. Rev. Bras. Hematol Hemoter. 2009; 31(5): 361-366. 
12. Brazil. Ministério da Saúde. Secretaria de Ciência, Tecnologia e Insumos Estratégicos. Departamento de Assistência Farmacêutica e Insumos Estratégicos. Relação nacional de medicamentos essenciais: Rename. Ministério da Saúde, Secretaria de Ciência, Tecnologia e Insumos Estratégicos, Departamento de Assistência Farmacêutica e Insumos Estratégicos. 7. ed. - Brasília: Ministério da Saúde, 2010.

13. Brazilian Pharmacopoeia. Agência Nacional de Vigilância Sanitária. Farmacopeia Brasileira. $6^{\mathrm{a}}$ ed. Brasília, 2019.

14. Lenardão EJ, Freitas RA, Dabdoub MJ, Batista ACF, Silveira CC. "Green chemistry": Os 12 princípios da química verde e sua inserção nas atividades de ensino e pesquisa. Quim Nova 2003; 26(1):123-129.

15. Gałuszka A, Migaszewski Z, Namiesnik J. The 12 principles of green analytical chemistry and the SIGNIFICANCE mnemonic of green analytical practices. Trends Analyt Chem. 2013; 50: 78-84.

16. Brazil. Agência Nacional de Vigilância Sanitária. Guia de controle de qualidade de produtos cosméticos. $2^{\mathrm{a}}$ ed. Brasília: Anvisa, 2008.

17. Cazedey ECL. Análise químico-farmacêutica e estudos de estabilidade e de dissolução de comprimidos de orbifloxacino [dissertation]. Araraquara (SP): Universidade Estadual Paulista "Júlio de Mesquita Filho", 2012.

18. Watson DG. Pharmaceutical Analysis E-Book: A Textbook for Pharmacy Students and Pharmaceutical Chemists. Elsevier Health Sciences, 2015. 